\title{
A Description of Seed Potato Systems in Kenya, Uganda and Ethiopia
}

\author{
Peter R. Gildemacher • Paul Demo • Ian Barker • Wachira Kaguongo • \\ Gebremedhin Woldegiorgis - William W. Wagoire - Mercy Wakahiu • Cees Leeuwis • \\ Paul C. Struik
}

Published online: 22 May 2009

(C) The Author(s) 2009. This article is published with open access at Springerlink.com

\begin{abstract}
Seed potato systems in East Africa are described and opportunities for improvement identified on the basis of interviews with potato producers in Kenya, Uganda and Ethiopia, and an assessment of Ralstonia solanacearum and virus disease levels in Kenya. 3\% of seed potato sold in Kenyan markets was virus free. Ralstonia solanacearum was found in $74 \%$ of potato farms. Less than $5 \%$ of the farmers interviewed source seed potato from specialized seed growers. Over 50\% rely entirely on farm-saved seed. Current seed potato prices justify this behavior. To improve the system the local and specialized chain need to be
\end{abstract}

\author{
P. R. Gildemacher $(\bowtie) \cdot$ W. Kaguongo \\ International Potato Center, \\ Nairobi, Kenya \\ e-mail: p.gildemacher@kit.nl \\ P. Demo \\ International Potato Center, \\ Lilongwe, Malawi \\ I. Barker \\ International Potato Center, \\ Lima, Peru \\ G. Woldegiorgis \\ Ethiopian Institute for Agricultural Research, \\ Holetta, Ethiopia \\ W. W. Wagoire \\ Kachwekano Zonal Agricultural Research \\ and Development Institute, \\ Kabale, Uganda \\ M. Wakahiu \\ Kenya Agricultural Research Institute, \\ Tigoni, Kenya \\ C. Leeuwis $\cdot$ P. C. Struik \\ Wageningen University and Research Centre, \\ Wageningen, The Netherlands
}

tackled simultaneously. To improve the local chain ware potato farmers require training on seed quality maintenance and managing bacterial wilt and viruses. Research into virus resistance and the effect of mixed virus infection on yield deserves attention. Private investment in seed potato production could increase volumes produced and reduce prices.

Resumen Se describen sistemas de semillas de papa en África del Este y se identifican oportunidades de mejora basándose en entrevistas con productores de papas en Kenia, Uganda y Etiopía y una evaluación de los niveles de las enfermedades causadas por Ralstonia solanacearum y virus en Kenia. El 3\% de la semilla de papa vendido en los mercados de Kenia estaba libre de virus. Se encontró Ralstonia solanacearum en $74 \%$ de las explotaciones agrarias de papa. Menos del 5\% de los agricultores entrevistados obtienen semillas de papa de agricultores especializados en semillas. Más del $50 \%$ dependen totalmente de las semillas almacenadas en la explotación agraria. Los precios actuales de semilla de papa justifican este comportamiento. Para mejorar el sistema, se debe abordar simultáneamente tanto la cadena local y la especializada. Para mejorar la cadena local, los agricultores de papa para consumo humano necesitan capacitación sobre el mantenimiento de la calidad de la semilla y manejo de la marchités bacteriana y virus. La investigación sobre resistencia a los virus y el efecto de la infección de mezcla de virus sobre el rendimiento merece atención. La inversión privada en la producción de semilla de papa podría aumentar los volúmenes de producción y reducir los precios.

Keywords Kenya $\cdot$ Uganda $\cdot$ Ethiopia $\cdot$ Bacterial wilt . Potato virus $\cdot$ Seed potato systems $\cdot$ Seed potato economics 


\section{Introduction}

In potato production the quality of seed potatoes planted is an important determinant of the final yield and quality (Struik and Wiersema 1999). If farm saved seed potatoes are used for several cropping cycles, without renewing the seed lot from a reliable source, seed-borne diseases cause severe yield and quality losses. This process of yield loss over seasons of seed recycling is generally called degeneration, and can be attributed to the accumulation of seed borne diseases (Gildemacher et al. 2007).

Turkensteen (1987) identified bacterial wilt, caused by Ralstonia solanacearum and virus diseases caused by PVY and PLRV as the major seed borne potato diseases in Africa, but also mentioned soft rot (caused by Erwinia chrysanthemi), Fusarium wilt and dry rot (caused by Fusarium solani) and Verticilium wilt (caused by Verticilium albo-atrum) as economically important seed borne diseases. Gildemacher et al. (2009) consider virus diseases and potato bacterial wilt as the most important seed borne potato diseases in Eastern Africa. Low seed potato quality is believed to be one of the major yield reducing factors in potato production in Sub Sahara Africa (Fuglie 2007). This contributes to the low average yields in Sub-Saharan African countries of around $8 \mathrm{Mg} / \mathrm{ha}$ on the continent compared to a world average of $16 \mathrm{Mg} / \mathrm{ha}$ (FAO 2008). Serious yield losses can be expected as a result of high infection rates with potato viruses (Reestman 1970).

The problem of seed degeneration has been solved in the Northern potato producing countries through specialized seed potato producers (hereafter called seed growers) who multiply seed potatoes from basic pathogen free starter seed. Consumption potato producers (hereafter called ware growers) maintain maximum production potential over the seasons by replacing their seed potato stock each season, or at least frequently, with high quality seed potatoes from a seed grower. This keeps the virus pressure in the entire cropping system low. This so-called "flush out" system is practised in more advanced potato cropping systems in the Western world (Struik and Wiersema 1999).

Different systems of seed potato multiplication have been initiated in potato growing developing countries in the world, including Sub-Sahara Africa (Monares 1987; Potts and Nikura 1987; Crissman et al. 1993), resulting in different scales of success. In spite of the many efforts with regards to seed potato system improvement, potato farmers in Kenya, Uganda and Ethiopia still identified seed potato quality as their major concern within their potato production system and it was prioritized as an important technical intervention area to improve smallholder potato profitability (Gildemacher et al. 2006).

In this paper the current status of the seed potato systems in Kenya, Uganda and Ethiopia is described on the basis of surveys of potato producers to assess their seed potato production practices. Furthermore an assessment was made of the level of potato viruses in the general seed stock available to farmers in Kenya, and the severity of bacterial wilt in Kenyan potato fields. On the basis of the data opportunities for seed system improvement in Kenya, Uganda and Ethiopia are discussed.

\section{Materials and Methods}

\section{Quantification of the Importance of Seed Borne Diseases}

To asses the importance of seed borne diseases, specific surveys were conducted in Kenya. Seed potatoes sold on rural markets were assessed via a survey for their level of infection with major potato diseases. With another survey, the level of bacterial wilt (Ralstonia solanacearum) in potato fields in major potato growing areas in Kenya was quantified.

\section{Potato Virus Survey in Kenya}

In September 2006 seed potatoes were sampled randomly in batches of 20 from four vendors in each of 11 rural markets, covering Nakuru, Nyandarua, Nyeri, Laikipia, Meru Central, Muranga and Kirinyaga districts, thus representing the major potato production zones of Kenya. Samples were carried to the laboratory in paper sample bags and stored until sprouting. Then Double Antibody Sandwich ELISA was conducted against four important potato viruses, PVY, PVX, PLRV and PVA, on the single tuber samples, using DAS ELISA from CIP, Lima (Salazar and Jayasinghe 2002).

\section{Bacterial Wilt Survey in Kenya}

Three major potato growing areas in Kenya, Kiambu, Nyandarua and Bomet district, were purposefully chosen to represent different potato farming systems in Kenya. Thirty five, 32 and 34 potato fields were selected in Kiambu, Nyandarua and Bomet district respectively. The fields were randomly selected along rural unpaved roads at intervals of about $2.5-5 \mathrm{~km}$. The severity of bacterial wilt was recorded in all potato fields of the visited farms by scoring the incidence of plants showing the characteristic symptoms of the disease. Fields with potato crops that had not yet developed a more or less closed canopy were not considered. The survey was conducted during the main rainy season of 2005, in the months of June, July and August when most farms had a well established potato crop. 
Table 1 Incidence of PLRV, PVY, PVX and PVA in seed potatoes sold at rural markets in Kenya, September 2006

\begin{tabular}{|c|c|c|c|c|c|c|c|}
\hline Market & District & PLRV & PVY & PVX & PVA & Virus free & Multiple infections \\
\hline Elburgon & Nakuru & 29 & 83 & 39 & 10 & 8 & 50 \\
\hline Kagio & Kirinyaga & 68 & 91 & 83 & 56 & 0 & 96 \\
\hline Karatina & Nyeri & 91 & 78 & 83 & 28 & 1 & 93 \\
\hline Kihingo & Laikipia & 71 & 48 & 100 & 9 & 0 & 79 \\
\hline Mau Narok & Nakuru & 61 & 83 & 30 & 15 & 9 & 68 \\
\hline Meru & Meru Central & 91 & 58 & 70 & 40 & 1 & 84 \\
\hline Molo & Nakuru & 49 & 70 & 64 & 14 & 6 & 66 \\
\hline Murang'a & Muranga & 95 & 100 & 64 & 64 & 0 & 100 \\
\hline Nanyuki & Meru Central & 96 & 100 & 55 & 65 & 0 & 98 \\
\hline Naru Moru & Nyeri & 63 & 29 & 46 & 65 & 6 & 75 \\
\hline North Kinangop & Nyandarua & 99 & 98 & 34 & 78 & 0 & 98 \\
\hline South Kinangop & Nyandarua & 74 & 94 & 23 & 65 & 3 & 83 \\
\hline Grand mean & & 74 & 77 & 57 & 42 & 3 & 82 \\
\hline
\end{tabular}

\section{Potato Farming Practices Survey}

A survey was conducted to document potato farming practices in Kenya, Uganda and Ethiopia. In each country first a rapid appraisal was executed, to allow for proper site selection and questionnaire development. The questionnaire was pre-tested in each country and adapted to local circumstances, and translated in Ethiopia. The survey was executed by specifically trained enumerators recruited locally within each country.

In Kenya, data collection took place between 10 and 29 October 2005. Meru Central and Nyandarua were selected as sample districts, as they were considered to best represent the whole of the Kenyan potato production system. A district is an administrative topographical unit, which is further sub-divided into divisions, locations and sub-locations, the latter being the smallest administrative unit. Six farmers were chosen randomly in half of the sublocations within each location in the sampled districts, to get a satisfactory number of sample households. The sample households were randomly picked from a list of all farm households in the village, provided by a village elder. In total 251 farmers were successfully interviewed, 100 in Meru Central district and 151 in Nyandarua district.

Kabale and Kisoro districts were selected to represent the potato farming system in Uganda. Districts are subdivided in counties, sub-counties, parishes and villages. All the four counties and the 25 potato producing sub-counties in Kabale and Kisoro districts were included in the study. One parish was randomly selected from each sub-county and one village was randomly selected within each parish. Six households were picked at random in each sampled village, from a list of households provided by a village elder, to assure a sufficiently large and representative sample. In all, 144 farmers out of 150 randomly selected were successfully interviewed.

In Ethiopia three major potato producing districts (woredas) were selected, Jeldu in West Shewa zone, Degem in North Shewa zone and Banja Shikudadin in Awi zone, as a cross section of potato production in the country. Within these districts six households were randomly selected within each kebele (village), resulting in 220 households that were successfully surveyed.

\section{Results}

Potato Virus Survey in Kenya

Table 1 shows the average infection rates for potato leaf roll virus (PLRV), potato virus Y (PVY), potato virus X (PVX) and potato virus A (PVA) in potatoes sold as seed potatoes on rural markets in Kenya. PLRV and PVY infection were highest. More than half of the sampled tubers were infected with PVX and slightly less than half of the potato tubers with PVA. Out of the total sample of 1,000 tubers, only 27 tubers were found to be entirely free of these four viruses.

\section{Bacterial Wilt Survey in Kenya}

The disease could be detected on the basis of outright symptoms in $74 \%$ of the farms. The incidence of wilting plants per farm was $0.78,1.09$ and $1.47 \%$ for Nyandarua, Kiambu and Bomet districts, respectively (Table 2). 
Table 2 Bacterial wilt incidence and prevalence in potato farms in three districts in Kenya, 2005

\begin{tabular}{lccc}
\hline District & Mean wilt incidence (\%) & Prevalence of bacterial wilt in farms (\%) & No. of farms sampled \\
\hline Nyandarua & 0.78 & 69 & 32 \\
Kiambu & 1.09 & 63 & 35 \\
Bomet & 1.47 & 91 & 34 \\
Mean & 1.12 & 74 & \\
\hline
\end{tabular}

Potato Farming Practices Survey

Two seed potato production and marketing systems or chains could be identified, here called the specialized chain and the local chain. In the specialized chain seed growers produce and sell seed potatoes as a business, which includes non-certified commercial multiplication of starter seed, which others would classify as 'informal' seed potato multiplication (Crissman et al. 1993; Thiele 1999; Tindimubona et al. 2000). The local chain can be characterized by the fact that seed potatoes are a by-product of ware potato production and are sold and traded locally, as also described by Crissman et al. (1993). Using the information of the surveys the importance of the different flows of seed potato has been quantified for Kenya, Uganda and Ethiopia.

\section{Seed Potato Sources}

Table 3 shows the sources of seed potatoes planted by farmers in Kenya, Uganda and Ethiopia. The dominant seed sources were the grower's own field and neighbours. In Uganda and Ethiopia the local market was an important source of seed potatoes, whereas this source was of less importance in Kenya.

In Kenya the number of farmers purchasing seed from seed growers was less than $1 \%$, while in Uganda it was $4 \%$. In West Shewa and Awi districts in Ethiopia it was comparably low with $3 \%$ and $2 \%$, respectively. In North Shewa, however, potato farmers indicated they had planted $29 \%$ of potato fields with seed from a seed grower. Table 3 suggests a renewal rate with seed potatoes from outside the own farm of $30-70 \%$ per season. This may be an overestimation.

\section{Seed Renewal Period}

Growers were asked whether they renewed seeds, and if so, after how many seasons. In Kenya, Uganda and Ethiopia $59 \%, 74 \%$ and $56 \%$ of the farmers indicated to never renew their seed potatoes respectively (Table 4). Those farmers who do renew their seed potatoes do so after an average 6 , 7 and 3 seasons, from which it can be computed that only 7 , 4 and $15 \%$ of the seed stock of Kenya, Uganda and Ethiopia respectively gets renewed each season from any of the possible sources outside the own farm.

\section{Seed Potato Management Practices by Ware Potato Producers}

As the majority of seed potatoes planted originate from ware growers rather than from seed growers, it is worthwhile considering the seed potato management practices that are applied by ware potato growers.

Table 5 indicates that the majority of farmers in Kenya and Uganda select their seed from the bulk of potatoes at harvest. In Uganda, $17 \%$ of the farmers practice some form of in-field selection of the best plants for seed, and $11 \%$ produce their seed in a separate seed plot. In Ethiopia and Kenya, these technologies are also practised, but less frequently.

In Ethiopia, half of the potato farmers leave in the soil potatoes that will later be used as seed. This apparently is

Table 3 Seed potato sources of farmers in Kenya, Uganda and Ethiopia (\%)

\begin{tabular}{|c|c|c|c|c|c|c|c|}
\hline & \multicolumn{2}{|l|}{ Kenya } & \multicolumn{2}{|l|}{ Uganda } & \multicolumn{3}{|l|}{ Ethiopia } \\
\hline & Meru Central & Nyandarua & Kabale & Kisoro & West Shewa & North Shewa & Awi \\
\hline Own field & 30 & 70 & 61 & 40 & 54 & 32 & 65 \\
\hline Neighbour & 66 & 28 & 16 & 15 & 12 & 10 & 3 \\
\hline Rural market & 4 & 1 & 19 & 42 & 31 & 29 & 31 \\
\hline Seed grower & 0 & 1 & 4 & 4 & 3 & 29 & 2 \\
\hline Number of respondents & 235 & 498 & 247 & 101 & 157 & 129 & 398 \\
\hline
\end{tabular}


Table 4 Percentage of farmers renewing their seed periodically, the average renewal period and the total fraction of potato seed renewed each season in Kenya, Uganda and Ethiopia

\begin{tabular}{lccc}
\hline & Kenya & Uganda & Ethiopia \\
\hline Does not renew seeds periodically (\%) & 59 & 74 & 56 \\
Does renew seeds periodically (\%) & 41 & 26 & 44 \\
Average renewal period (seasons) & 6 & 7 & 3 \\
Seed stock renewed each season (\%) & 7 & 4 & 15 \\
\hline
\end{tabular}

the method farmers prefer to store seed potatoes until the next season. Ethiopian farmers store their seed substantially longer than Kenyan and Ugandan farmers (Fig. 1), as many only grow potatoes once a year. Kenyan potato farmers only store seed for 1-2 months before planting compared to 2-3 months by Ugandan potato farmers.

In Kenya and Ethiopia, 15 and $23 \%$ of the farmers indicated they store their seed under diffused light conditions, either in the house or in a special store whereas in Uganda $46 \%$ of farmers store seed potatoes under such conditions. Diffuse light assures seed potatoes with strong sprouts. In Kenya, $51 \%$ of the farmers store seed in a dark store, which they generally use for maize storage (Table 6).

Different techniques to stimulate the sprouting of seed potatoes, to assure they are ready on time for planting were mentioned (Table 7). In Kenya, burying potatoes in an underground pit is the most popular method. Covering the potatoes with crop residues, grass or manure is practised frequently in all three countries. Bringing the potatoes to a warm place in the house was used by more than $20 \%$ of the farmers in Ethiopia and Uganda, while also putting the seed potatoes in bags was frequently mentioned. Thirty two, 33 and $24 \%$ of farmers in respectively Kenya, Uganda and Ethiopia did not make any extra effort to stimulate sprouting.

\section{Specialized Seed Potato Multiplication}

In all three countries national research organizations are the sole source of modest amounts of disease free starter seed, meant for further multiplication by seed growers. In Kenya formal quality control and certification regulations exist for multiplication of starter seed, but few seed growers choose to make use of this system. They prefer to multiply seed potato without certification, and trade the seed to nearby farmers based on their reputation for quality seed potato. In
Uganda a seed potato growers association with a self policing quality control system (Tindimubona et al. 2000) multiplies a significant proportion of the starter seed available, while the remainder is distributed through NonGovernmental Organizations (NGOs) to farmer groups, or is bought by individual seed potato multipliers. In Ethiopia starter seed is multiplied by farmer groups, collaborating with the potato research center (Getachew and Mela 2000; German 2006), without an elaborate quality control system.

\section{Estimated Volumes of Seed Potatoes in the Specialized} Seed Potato Chain

A simple model was developed to calculate the final multiplication rate of the starter seed produced by the national research programmes (Fig. 2) based on a few basic estimates. Average seed potato multiplication rate by seed growers was estimated fairly low at 7 , considering the fact they generally do not have irrigation facilities. Not all starter seed ends up in the care of seed growers (Tindimubona et al. 2000). Also ware growers purchase starter seed, with the objective to obtain a new variety, or they receive it through an $\mathrm{NGO}$ or a development project. It was estimated that $60 \%$ of the starter seed is purposefully multiplied by specialized growers, while the other $40 \%$ is planted by ware potato farmers. Seed growers are further assumed to sell $60 \%$ of their seed yield after a single multiplication, $32 \%$ after the second multiplication, and $8 \%$ after a third multiplication.

Seed sold by multipliers is replanted several generations by ware potato farmers. Thiele (1999) found that in the Andes certified seed potato gave increased yields compared to local seed potatoes up to the third generation of re-use in farmer fields. Here we assumed a yield increase during only two seasons of re-use as the vast majority of high-quality
Table 5 Seed potato selection methods practiced in Kenya, Uganda and Ethiopia (\% of farmers)

${ }^{a}$ farmers selecting seeds from the best plants or best portion of their fields

\begin{tabular}{lccc}
\hline & Kenya & Uganda & Ethiopia \\
\hline Separate seed plot & 3 & 11 & 2 \\
Positive selection $^{\mathrm{a}}$ & 3 & 17 & 9 \\
Seed sized tubers from bulk harvest & 92 & 72 & 40 \\
Buy seeds from best plot neighbour & 2 & 0 & 0 \\
Preserve potatoes in the soil & 0 & 0 & 49 \\
\hline
\end{tabular}


Fig. 1 Storage duration (months) before replanting of seed potato harvested by ware potato growers in Kenya, Uganda and Ethiopia
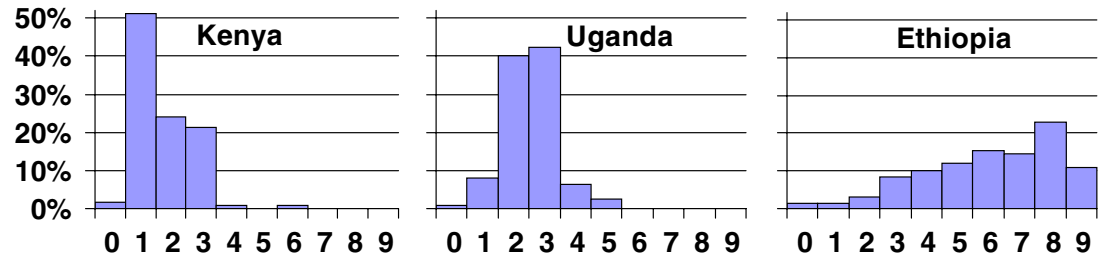

seed in the three countries is not certified. Furthermore all seed was assumed to have lost its yield advantage compared to local seed after the fourth planting from being starter seed. As ware potato farmers sell their large tubers as ware potatoes, and only replant the smaller tubers, the average multiplication rate in ware potato farmers' fields was put at 2 .

With these conservative estimates of the variables entered into the model (Fig. 2), the total expected multiplication factor for high-quality starter seed injected into the seed system can be calculated as the sum of all grey squares. The grey squares represent high quality seed potatoes planted for ware potato production. In Table 8 the average amounts of starter seed produced in Kenya, Uganda and Ethiopia are used to calculate the total amount of high quality seed potatoes available yearly in the three countries. When projecting this against the calculated seed requirement in the three countries, this means that an estimated $1.6 \%, 2.4 \%$ and $1.3 \%$ of the total seed requirement is met by seed potatoes of relatively high quality, originating from basic seed initially sold by the national research organizations.

\section{Seed Potato Economics}

Table 9 presents economic data regarding seed potato use in Kenya, Uganda and Ethiopia. The acceptable price premium for high quality seed has been calculated on the basis of a marginal rate of return (MRR) to the farmer of $200 \%$, meaning a farmer gets a net return of two dollars for every dollar he invests in seed potatoes. Although it has been suggested that a MRR of $100 \%$ can be considered sufficient for a farmer to decide to invest in a certain technology (Cassaday 1988), we here prefer a higher minimum acceptable MRR because the return on the investment in high quality seed potato will not be achieved in a single season, but over a period of three seasons. For an urgently cash short smallholder potato farmer, a higher MRR is thus required as an incentive for technology adoption. Under this assumption price premiums on seed potatoes compared to the ware potato price of 26 to $87 \%$ are acceptable, under the current average yield levels and ware potato prices in the seven sample districts. On average, a price premium on high quality seed potato of $49 \%$ compared to price of ware potato, is acceptable.

\section{Discussion}

\section{Potato Disease Levels}

The virus levels measured in the survey were substantially higher than those found in an earlier survey in Kenya (Were et al. 2003), in which less than 25\% infection with PLRV was recorded. However, their figures were entirely based on visual observation, and samples were only taken from plants identified as infected, for confirmation through ELISA. This could have resulted in an underestimate of the actual infection rate. A survey in Uganda revealed PLRV and PVX levels of 17 and $35 \%$, respectively (Kakuhenzire et al. 2000), which is also substantially lower than what was found in tubers from markets in Kenya. This study was, however, done from leaf samples rather than tuber samples, which could underestimate final tuber infection levels, especially when samples are taken earlier in the season. An extensive survey in Iran showed an average of $52 \%$ mixed infection rates in a similar leaf sample survey (Pourrahim et al. 2007). The results from the survey confirm observations of potato scientists in Kenya, that potato virus diseases are typically visible on between $20 \%$ and $80 \%$ of potato plants in ordinary potato fields (non-published field observations). The results strengthen the priority setting by potato farmers in Kenya, who put low seed potato quality at the top of the list of their problems (Gildemacher et al. 2006). It is likely that the high levels of mixed virus infection measured in the survey, are contributing to the low average potato yields in Kenya measured through the farmer yield estimates.

Table 6 Seed potato storage techniques used by potato producers in Kenya, Uganda and Ethiopia (\% of farmers)

\begin{tabular}{lccc}
\hline & Kenya & Uganda & Ethiopia \\
\hline Farmers storing seed potatoes & 92.4 & 88.7 & 94.3 \\
Storage method & & & \\
Diffuse light store & 10 & 31 & 5 \\
Dark store & 51 & 16 & 2 \\
In the field, not harvested & 0 & 0 & 47 \\
Dark space in the house & 13 & 37 & 28 \\
Light space in the house & 5 & 15 & 18 \\
Underground pit & 21 & 1 & 0 \\
\hline
\end{tabular}


Table 7 Dormancy breaking techniques used by farmers to force sprouting of seed potatoes in Kenya, Uganda and Ethiopia ( $\%$ of farmers)

\begin{tabular}{lcrr}
\hline & Kenya & Uganda & Ethiopia \\
\hline Wait & 32 & 33 & 24 \\
Put in an underground pit & 29 & 5 & 0 \\
Put in bags & 7 & 18 & 29 \\
Put in a warm place in the house & 6 & 16 & 23 \\
Cover with crop residues / grass / manure & 26 & 5 & 17 \\
Other & 0 & & 6 \\
\hline
\end{tabular}

The data from the survey on bacterial wilt incidence and prevalence shows that the disease, considered a quarantine disease in many potato growing countries (Elphinstone 2005), is endemic in the Kenyan potato farming system. Although the measured levels of incidence do not immediately seem alarming from an economic point of view, they can fluctuate dramatically according to the growing period of the crop in correlation with the relative humidity. In case of a severe outbreak of the disease affected farmers can consider their yield lost, as there is no chemical cure for infected plants. Farmers in Uganda and Kenya considered bacterial wilt a priority problem in their production (Gildemacher et al. 2009).

\section{Seed Potato Management by Ware Producers}

From the fraction of farmers that did renew seeds, in Kenya and Uganda the majority did so after eight seasons, compared to three seasons in Ethiopia. The shorter average renewal period in Ethiopia can be explained by the larger number of farmers growing potatoes only once a year, making seed potato storage more cumbersome (Eshetu et al. 2005) compared to Kenya and Uganda, where bi-modal potato farming is dominant.

The seed source data in Table 3 indicate a much higher seed renewal rate than Table 4 . This is most likely related to the fact that many farmers do not make a distinction

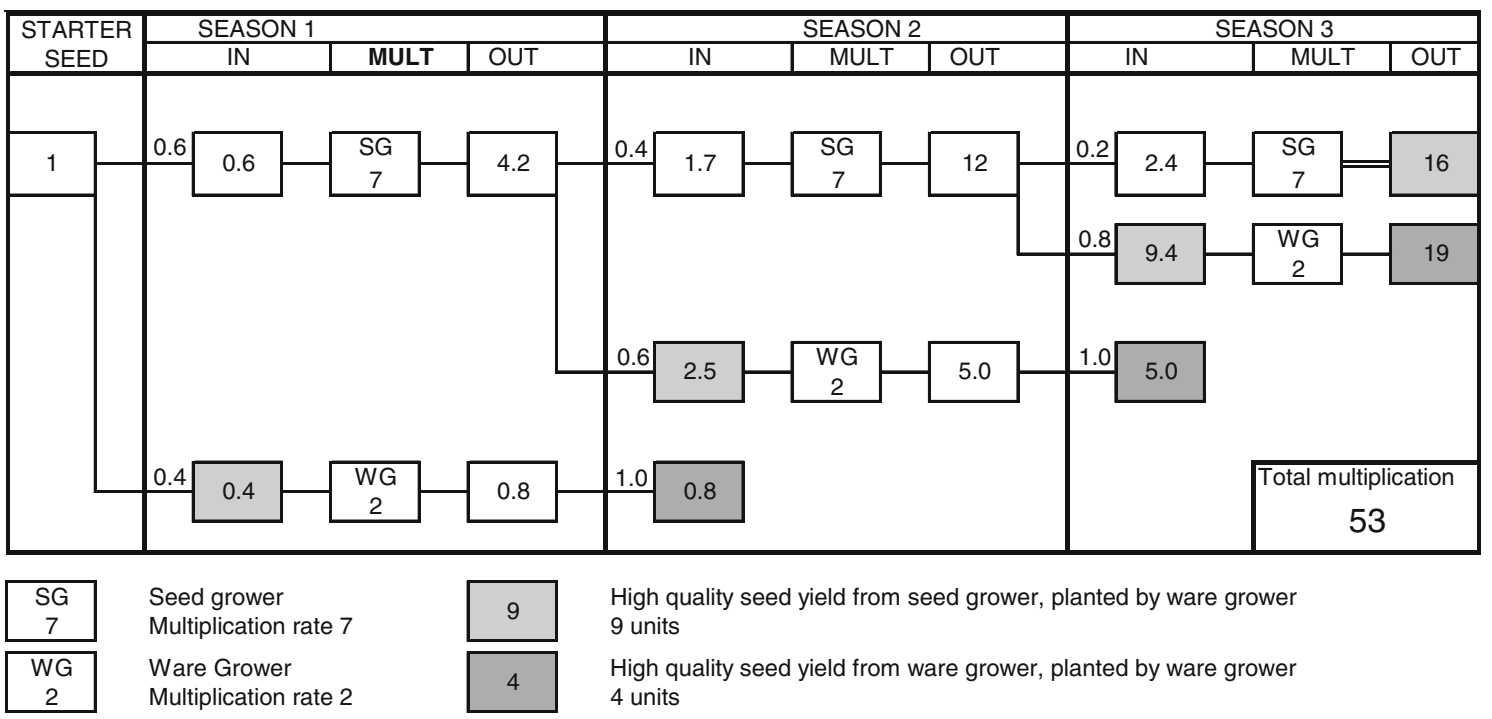

Variables

Fraction of starter seed to seed growers

Fraction of 1st generation seed grower seed multiplied 2nd season

Fraction of 2nd generation seed grower seed multiplied 3rd season

Multiplication rate seed grower

Multiplication rate ware growe

Assumptions

Total maximum 3 multiplications

Starter seed, 1 st generation and 2nd generation retains quality 2 seasons in ware growers field

3rd generation retains quality 1 season in ware growers field

Fig. 2 Model of starter seed potato multiplication rate in the seed potato systems of Kenya, Uganda and Ethiopia 
Table 8 Estimated amounts of high quality seed available to the potato growing systems in Kenya, Uganda and Ethiopia compared to the total seed potato requirement

\begin{tabular}{lcccccc}
\hline Country & $\begin{array}{c}\text { Basic seed available for } \\
\text { further multiplication } \\
(\mathrm{Mg} / \text { year) }\end{array}$ & $\begin{array}{c}\text { Estimated amount of } \\
\text { high quality seed } \\
(\mathrm{Mg} / \text { year) }\end{array}$ & $\begin{array}{c}\text { Seed rate good } \\
\text { quality seed } \\
(\mathrm{Mg} / \mathrm{ha})\end{array}$ & $\begin{array}{c}\text { Area planted } \\
\text { quality seed } \\
\text { (ha/year) }\end{array}$ & $\begin{array}{c}\text { Potato area } \\
\text { (ha/year) }\end{array}$ & $\begin{array}{c}\text { Proportion } \\
\text { quality seed } \\
(\%)\end{array}$ \\
\hline Kenya & 71 & 3,763 & 2 & 1,882 & 116,000 \\
Uganda & 103 & 5,459 & 2.5 & 2,184 & 90,000 \\
Ethiopia & 78 & 4,134 & 2 & 2,067 & 1.6 \\
\hline
\end{tabular}

${ }^{a}$ Personal communication Mercy Wakahiu and John Karinga (Kenya); William Wagoire (Uganda) and Gebremedin Woldegiorgis (Ethiopia)

${ }^{b}$ Basic seed leaving the formal multiplication system is estimated to be multiplied a factor 53 before being degenerated to the level of "farmer seed" (Fig. 2)

between seed source and variety source. As the process of seed degeneration and its underlying causes are poorly understood by smallholder potato growers (Crissman et al. 1993), producers may have mentioned the initial source of seed of the potato variety they were growing, rather than the place where their seed came from that very season. As a result the sources other than the own farm were overestimated. As such the seed renewal rates in Table 4 provide the most realistic estimate.

\section{Seed Potato Economics}

Potato producers in Kenya, Uganda and Ethiopia are, under the current circumstances in the seed and ware potato market, making an economically sound decision by not investing much in renewing their seed stock. In all districts accept Awi, the current cost of seed potatoes is higher than the calculated acceptable price for high quality seed potatoes (Table 9). However, these average figures are masking the fact that under specific circumstances, for example a higher ware potato price or higher yields through better production practices, regular investment in high quality seed potatoes can be economically feasible.

Improving Seed Quality in the Local Seed Potato Chain

As Thiele (1999) indicates, the local chain of seed potato production and marketing delivers an important service to

Table 9 Acceptable price premium for high quality seed potatoes in Kenya, Uganda and Ethiopia

\begin{tabular}{|c|c|c|c|c|c|c|c|c|}
\hline & \multicolumn{2}{|l|}{ Kenya } & \multicolumn{2}{|l|}{ Uganda } & \multicolumn{3}{|l|}{ Ethiopia } & \multirow[t]{2}{*}{ Average $^{c}$} \\
\hline & $\begin{array}{l}\text { Meru } \\
\quad \text { Central }\end{array}$ & $\begin{array}{l}\text { Nyan- } \\
\text { darua }\end{array}$ & Kabale & Kisoro & $\begin{array}{l}\text { West } \\
\text { Shewa }\end{array}$ & $\begin{array}{l}\text { North } \\
\quad \text { Shewa }\end{array}$ & Awi & \\
\hline Average yield (Mg/ha) & 8.8 & 9.2 & 5.3 & 6.8 & 7.7 & 12.3 & 5.1 & 7.9 \\
\hline Production costs $(\$ / \mathrm{ha})$ & 510 & 475 & 278 & 244 & 366 & 358 & 394 & 375 \\
\hline Seed rate $(\mathrm{Mg} / \mathrm{ha})$ & 1.5 & 1.6 & 1.1 & 1.0 & 1.1 & 1.1 & 1.6 & 1.3 \\
\hline Ware price $(\$ / M g)$ & 80 & 45 & 88 & 72 & 62 & 79 & 91 & 74 \\
\hline Total yield gain $(\mathrm{Mg} / \mathrm{ha})^{\mathrm{a}}$ & 2.1 & 2.2 & 1.2 & 1.6 & 1.8 & 2.9 & 1.2 & 1.9 \\
\hline Value yield gain $(\$ / \mathrm{ha})$ & 168 & 99 & 110 & 117 & 114 & 232 & 111 & 139 \\
\hline Min. MRR $^{\mathrm{b}}$ & 200 & 200 & 200 & 200 & 200 & 200 & 200 & 200 \\
\hline Acceptable investment $(\$ / \mathrm{ha})$ & 56 & 33 & 37 & 39 & 38 & 77 & 37 & 46 \\
\hline Acceptable seed price $(\$ / \mathrm{Mg})$ & 117 & 65 & 121 & 111 & 98 & 148 & 115 & 110 \\
\hline $\begin{array}{l}\text { Acceptable additional cost seed over ware } \\
(\%)\end{array}$ & 45 & 45 & 38 & 54 & 58 & 87 & 26 & 49 \\
\hline $\begin{array}{l}\text { Current additional cost seed over ware } \\
(\%)^{\mathrm{d}}\end{array}$ & 67 & 124 & 145 & 229 & 121 & 199 & 5 & \\
\hline
\end{tabular}

${ }^{a}$ Estimated yield gain through use of high-quality seed potatoes over three seasons; generation 1, 2 and 3: 17\%, 16\% and 10\% respectively (Thiele 1999); assumed area planted under improved seed $0.25,0.5$ and 1 ha in season 1,2 and 3 respectively

${ }^{\mathrm{b}}$ Marginal Rate of Return; A MRR of $200 \%$ in a three-season period is considered fair to assure farmers are willing to risk investing in high quality seed potatoes

${ }^{\mathrm{c}}$ Average based on average yield, production cost, seed rate and ware price over the 7 sample districts

${ }^{\mathrm{d}}$ Current seed potato price as estimated by farmers (average of all sources of seed) 
potato producers. The local chain produced more than $95 \%$ of the volume of seed potatoes in the three countries. It has to be considered how the quality of seed potatoes from this source can be improved. This requires an alternative outlook on seed potato production in which each ware potato farmer is considered to contribute to the overall quality of seed potatoes in the system.

From the survey several opportunities for improving the management of seed potato quality by ware potato growers can be derived. Management of virus diseases and bacterial wilt by ware growers is a priority as the diseases are endemic in the potato production system. Seed potato storage technology used by ware potato producers can be improved. Furthermore better seed potato multiplication and selection techniques can be applied by ware growers. Multiplication of high quality seed potatoes in nurseries by ware potato producers using the 'small seed plot technique' (Aguirre et al. 1999; Kinyua et al. 2001, 2005), positive seed potato selection by ware potato farmers (Gildemacher et al. 2007) and diffused light storage (Potts 1983) have shown to be useful technologies for improving seed potato quality management by ware growers.

Further research effort into the development of well adapted and marketable potato varieties with resistance to major potato viruses is highly relevant for the improvement of the quality of seed potatoes in the local chain. Further quantification of the importance of yield losses as a result of mixed infection with potato viruses is needed. This research shows very high incidences of four major yield reducing potato viruses in Kenya, but the actual yield loss as a result of these high levels of infection and the impact of resistance to some of these viruses deserves further study.

Improving Efficiency in the Specialized Chain

In spite of the limited percentage of seed potatoes deriving from seed growers, the specialized chain should not be disregarded. Table 9 shows that quality seed potatoes can fetch an average $50 \%$ price premium under the current average production and prices and still provide the buyer with a healthy profit on his investment. Ware potato producers turning into informal seed potato multipliers for profit in Ethiopia (Eshetu et al. 2005; German 2006), members of the Ugandan National Seed Potato Producers Association (UNSPPA) (Tindimubona et al. 2000), the short lived commercial success of large scale seed potato production by ADC in Kenya (Crissman et al. 1993), and individual Kenyan seed potato multipliers trading on their reputation, are the living proof of a potential for economically sustainable seed potato farming.

From Fig. 2, entry points for increasing the impact of the specialized seed potato chain can be identified. The amount of starter seed produced and marketed can be increased, the fraction of starter seed multiplied at least twice by specialized seed potato multipliers can be improved, and also the multiplication rate of seed potatoes grown by seed growers could be higher.

Crissman et al. (1993) suggest commercialization of the production of starter seed as a strategy for increasing the effect of the specialized chain on the seed potato quality of the entire system. However, until there are other, commercial, actors taking on the role of starter seed potato producer, the small volumes produced by national research organizations are vital to the seed potato systems as the single source of tested disease free starter seed. Research organizations could improve the efficiency of their starter seed production by investigating new technological options for multiplication, well suited to the relatively small amounts currently required in the three countries. They can invest in the development of cost effective tissue culture techniques for rapid multiplication, cheap and easyto-use disease testing methods and the adaptation of hydroponics and aeroponics techniques for minituber production.

Under the current circumstances the limited starter seed that is available is not multiplied with maximum efficiency (Tindimubona et al. 2000; Eshetu et al. 2005) largely because the number of skilled seed potato multipliers is at present small in all three countries. A larger number of commercial seed growers is desirable. The question remains as to how the further development of a class of seed growers can be facilitated, and how quality control systems can be shaped that answer to local needs.

All actors in this sector need to accept the presence of a local and a specialized seed potato chains. The local chain will continue to exist as it fits in a risk avoidance strategy by ware potato producers in reaction to uncertain ware potato prices, cash shortage and risk of crop failure. Simultaneously, the specialized seed potato chain requires further development to offer affordable high quality seed potatoes for those farmers who have the ability to realize its yield potential.

Open Access This article is distributed under the terms of the Creative Commons Attribution Noncommercial License which permits any noncommercial use, distribution, and reproduction in any medium, provided the original author(s) and source are credited.

\section{References}

Aguirre, G., J. Calderon, D. Buitrago, V. Iriarte, J. Ramos, J. Blajos, G. Thiele, and A. Devaux. 1999. Rustic seedbeds: a bridge between formal and traditional potato seed systems in Bolivia. Impact on a changing world; International Potato Center Program Report 1997/ 1998. Lima: CIP. 
Cassaday, K. 1988. From agronomic data to farmer recommendations: an economics training manual. Mexico: CIMMYT.

Crissman, C.C., L.M. Crissman, and C. Carli. 1993. Seed potato systems in Kenya: a case study. Lima: CIP.

Elphinstone, J.G. 2005. The current bacterial wilt situation: a global overview. In Bacterial wilt disease and the Ralstonia solanacearum species complex, ed. C. Allen, P. Prior, and A.C. Hayward, 9-28. St. Paul: APS.

Eshetu, M., O.E. Ibrahim, and B. Etenesh. 2005. Improving potato seed tuber quality and producers' livelihoods in Hararghe, Eastern Ethiopia. Journal of New Seeds 7(3): 31-56.

FAO. 2008. http://faostat.fao.org/site/567/default.aspx, June 2008. Rome: FAO.

Fuglie, K.O. 2007. Priorities for potato research in developing countries: results of a survey. American Journal of Potato Research 84(5): 353-365.

German, L. 2006. Approaches for mountain regions: Operationalizing systems integration at farm and landscape scales. AHÍ working paper 21. Kampala: AHÍ.

Getachew, T., and A. Mela. 2000. The role of SHDI in potato seed production in Ethiopia: Experience from Alemaya integrated rural development project. In: 5th African Potato Association Conference, 109-112. Kampala: APA.

Gildemacher, P.R., P. Maina, M. Nyongesa, P. Kinyae, W. Gebremedhin, Y. Lema, B. Damene, T. Shiferaw, R. Kakuhenzire, I. Kashaija, C. Musoke, J. Mudiope, I. Kahiu, and O. Ortiz. 2006. Participatory analysis of the potato knowledge and information system in Ethiopia, Kenya and Uganda. In Innovation Africa: enrichting farmers' livelihoods, ed. P.C. Sanginga, A.W. Bayer, S. Kaaria, J. Njuki, and C. Wettasinha, 203-219. London: Earthscan.

Gildemacher, P., P. Demo, P. Kinyae, M. Nyongesa, and P. Mundia. 2007. Selecting the best plants to improve seed potato. LEISA Magazine 23(2): 10-11.

Gildemacher, P., W. Kaguongo, O. Ortiz, A. Tesfaye, G. Woldegiorgis, W. Wagoire, R. Kakuhenzire, P. Kinyae, M. Nyongesa, P. Struik, and C. Leeuwis. 2009. Improving potato production in Kenya, Uganda and Ethiopia: a system diagnosis. Potato Research. doi:10.1007/s11540009-9127-4

Kakuhenzire, R., J.J. Hakiza, B. Mateeka, B. Lemaga, L. Salazar, and M. Olanya. 2000. Incidence and importance of potato viruses in southwestern Uganda. In: 5th Triennial African Potato Association Conference, 285-290. Kampala: APA.
Kinyua, Z.M., J.J. Smith, C. Lung'aho, M. Olanya, and S. Priou. 2001. On-farm successes and challenges of producing bacterial wilt-free tubers in seed plots in Kenya. African Crop Science Journal 9(1): 279-285.

Kinyua, Z.M., M. Olanya, J.J. Smith, R. El-Bedewy, S.N. Kihara, R.K. Kakuhenzire, C. Crissman, and B. Lemaga. 2005. Seedplot technique: empowerment of farmers in production of bacterial wilt-free seed potato in Kenya and Uganda. In: Bacterial wilt disease and the Ralstonia solanacearum species complex.

Monares, A. 1987. Analytical framework for design and assessment of potato seed programs in developing countries. The social sciences at CIP Report of the third social science planning conference, held at CIP, Lima, Peru, September 7 10, 1987.

Potts, M.J. 1983. Diffuse light potato seed storage as an example of technology-transfer - a case study. American Potato Journal 60 (4): 217-226.

Potts, M.J. and S. Nikura. 1987. Seed potato farm developed in Burundi encourages new ideas and techniques. Agriculture International 39(9-10): 266-270.

Pourrahim, R., S. Farzadfar, A.R. Golnaraghi, and A. Ahoonmanesh. 2007. Incidence and distribution of important viral pathogens in some Iranian potato fields. Plant Disease 91(5): 609-615.

Reestman, A.J. 1970. Importance of the degree of virus infection for the production of ware potatoes. Potato Research 13(4): 248268.

Salazar, L. and U.E. Jayasinghe. 2002. Techniques in plant virology at CIP. Lima: CIP.

Struik, P.C. and S.G. Wiersema. 1999. Seed potato technology. Wageningen: Wageningen University Press.

Thiele, G. 1999. Informal potato seed systems in the Andes: why are they important and what should we do with them? World Development 27(1): 83-99.

Tindimubona, S., R. Kakuhenzire, J.J. Hakiza, W.W. Wagoire, and J. Beinamaryo. 2000. Informal production and dissemination of quality seed potato in Uganda. In 5th African Potato Association Conference, 99-104. Kampala, APA.

Turkensteen, L.J. 1987. Survey of diseases and pests in Africa: fungal and bacterial diseases. Acta Horticulturae 213: 151-159.

Were, H.K., R.D. Narla, J.H. Nderitu, and H.L. Weidemann. 2003. The status of potato leafroll virus in Kenya. Journal of Plant Pathology 85(3): 153-156. 